\title{
Nota de Investigacion/Research Note
}

\author{
Reproducción sexual del coral Pocillopora damicornis \\ al sur del Golfo de California, México
}

\author{
Sexual reproduction of the coral Pocillopora damicornis \\ in the southern Gulf of California, Mexico
}

\author{
HE Chávez-Romo ${ }^{1,2}$, H Reyes-Bonilla ${ }^{2 *}$ \\ ${ }^{1}$ Facultad de Ciencias Marinas, Instituto de Investigaciones Oceanológicas, Universidad Autónoma de Baja California, Km 106 \\ Carretera Tijuana-Ensenada, Ensenada, CP 22860, Baja California, México. \\ 2 Departamento de Biología Marina, Universidad Autónoma de Baja California Sur, Carretera al Sur km 5.5, La Paz, CP 23080, \\ Baja California Sur, México.*E-mail: hreyes@uabcs.mx
}

\section{Resumen}

La especie de coral Pocillopora damicornis es una de las dominantes en sistemas arrecifales del Pacífico oriental, y se distingue por presentar variaciones geográficas en cuanto a su modo de reproducción. En el Pacífico mexicano no se ha investigado la reproducción de esta especie, lo cual es importante ya que sus poblaciones se encuentran recuperándose de las mortalidades acaecidas por el blanqueamiento coralino producto de El Niño 1997-98. En este estudio se determinó el patrón reproductivo de $P$. damicornis a partir de análisis histológicos de colonias individuales en Punta Gaviotas (24.5 $\mathrm{N})$, al suroeste del Golfo de California, México. Los resultados indican que P. damicornis es una especie hermafrodita con desarrollo simultáneo de gametos femeninos y masculinos. Se denotaron cuatro estadios de desarrollo para cada tipo de célula sexual, que corresponden a los definidos en otras regiones del Pacífico oriental. Los gametos se observaron entre junio y noviembre (verano a otoño) en 2001, y de mayo a julio en 2002. No se encontraron plánulas, aunque si se detectó la presencia de ovocitos maduros y espermatozoides (estadio IV) por un periodo de cinco meses (julio a noviembre) en 2001, y de junio a julio en 2002 . Este hallazgo advierte sobre la ocurrencia de poblaciones reproductivamente activas de P. damicornis en el Golfo de California, las cuales liberan gametos al medio. La aparición de óvulos y espermatozoides se dio de manera sincrónica y durante la época cálida, por lo que la periodicidad reproductiva de la especie debe estar controlada por la temperatura. También se observó herencia materna de zooxantelas, y la presencia en el mismo mes de gametos en estadio temprano en algunas colonias mientras otras contenían gametos maduros.

Palabras clave: Pocillopora damicornis, madurez sexual, Golfo de California, temperatura, desove.

\begin{abstract}
Pocillopora damicornis, one of the dominant coral species in reef systems of the eastern Pacific, presents geographic variation in its reproductive mode. There is no information, however, on the reproduction of this species in the Mexican Pacific, and such knowledge is relevant since the populations are in active recovery after bleaching and mortality caused by the 1997-98 El Niño event. In this study we determined the reproductive pattern of $P$. damicornis from histological analyses of ramets collected at Punta Gaviotas $\left(24.5^{\circ} \mathrm{N}\right)$, southwestern Gulf of California, Mexico. Our results indicate that $P$. damicornis is a hermaphroditic species with simultaneous development of female and male gametes. Four developmental stages were denoted for each type of sexual cell, corresponding to those defined in studies conducted elsewhere in the eastern Pacific. Gametes were observed from June to November (summer/fall) 2001 and from May to July 2002. No planulae were found, although mature oocytes and spermatozoa (stage IV) were detected during a five-month period (July to November) in 2001, and in June and July 2002. This finding indicates the occurrence of reproductively active populations of $P$. damicornis in the Gulf of California that broadcast gametes. The occurrence of ova and sperm was synchronous during the warm season, and thus temperature most likely controls the reproductive periodicity of this species. Maternal inheritance of zooxanthellae was observed, as well as the presence of gametes in early and late developmental stages in different colonies but in the same month.
\end{abstract}

Key words: Pocillopora damicornis, sexual maturity, Gulf of California, temperature, broadcast spawning.

\section{Introducción}

Dentro de los corales escleractinios, el género Pocillopora Lamarck 1801 ha sido objeto de múltiples estudios sobre su

\section{Introduction}

Among the Scleractinian corals, the reproductive biology of the genus Pocillopora Lamarck 1801 has been extensively 
biología reproductiva (Richmond 1997). Se sabe que estos corales pueden reproducirse tanto de manera sexual como asexual (por fragmentación; Highsmith 1982), aunque la primera es la estrategia predominante (Harrison y Wallace 1990). Los pocilopóridos son hermafroditas (Richmond y Hunter 1990), pero a pesar de ello, el género presenta diferencias geográficas en su modo de producción de gametos; en algunas áreas del Pacífico las especies llevan a cabo fecundación interna e incuban sus larvas plánulas (Stoddart 1983, Ward 1992), mientras que en otras la fecundación y desarrollo larval se realiza en la columna de agua (Stoddart y Black 1985, Glynn et al. 1991).

Como lo indican las revisiones sobre el tema (Harrison y Wallace 1990, Richmond 1997), la especie más estudiada del género bajo la perspectiva reproductiva es Pocillopora damicornis (Linnaeus 1758). Este coral se distribuye desde el Mar Rojo y el este de África hasta la costa occidental de América, y en este continente sus poblaciones se distribuyen desde México (Golfo de California) hasta Ecuador, incluyendo todas las islas oceánicas cercanas (Glynn y Ault 2000, PérezVivar et al. 2006); además es considerado el coral dominante en el Pacífico oriental (Glynn 2004).

A lo largo del Pacífico occidental y central, P. damicornis incuba sus plánulas (Ward 1992), se reproduce en primavera y verano austral (noviembre a marzo), en días de luna nueva o llena. En contraste, en el Pacífico oriental (de la Isla del Caño, Costa Rica, a las Islas Galápagos, Ecuador) produce desoves sincrónicos de gametos y éstos maduran todo el año e indistintamente durante las lunas nueva y llena (Glynn et al. 1991). No existe referencia alguna para México sobre la biología reproductiva de corales duros, aunque existen registros de la intensidad de reclutamiento en varias especies (ReyesBonilla y Calderón-Aguilera 1994, Glynn y Leyte-Morales 1997, Medina-Rosas et al. 2005, López-Pérez et al. 2007). El presente trabajo muestra la primera evidencia de reproducción exitosa de $P$. damicornis en México, fundamentada con el hallazgo de gametos maduros listos para liberarse a la columna de agua. La información es muy relevante considerando el status actual de las comunidades de coral del Pacífico mexicano, las cuales están en pleno proceso de recuperación luego de haber sido severamente impactadas por el evento de El Niño de 1997-98 (Reyes-Bonilla et al. 2002).

\section{Materiales y métodos}

Se llevaron a cabo muestreos mensuales de ejemplares de $P$. damicornis (ramas de colonias individuales) entre mayo de 2001 y julio de 2002, en la zona conocida como Punta Gaviotas (fig. 1), dentro de la Bahía de La Paz. El día de luna llena de cada mes se recolectaron 20 especímenes por medio de buceo autónomo y a una profundidad de 2 a $5 \mathrm{~m}(n=300)$. Los corales se fijaron en formol al $4 \%$ preparado con agua de mar, durante un periodo de $24 \mathrm{~h}$, se lavaron en agua corriente por 24 $\mathrm{h}, \mathrm{y}$ posteriormente fueron preservados en alcohol etílico al 70\% (Glynn et al. 1991). studied (Richmond 1997). These corals are known to reproduce both sexually and asexually (by fragmentation; Highsmith 1982), but the former is the predominant strategy (Harrison and Wallace 1990). Even though pocilloporids are hermaphroditic species (Richmond and Hunter 1990), the genus presents geographic differences in its mode of gamete production. In some areas of the Pacific, species undergo internal fertilization and incubate the planula larvae (Stoddart 1983, Ward 1992), whereas in others, fertilization and larval development occur in the water column (Stoddart and Black 1985, Glynn et al. 1991).

As indicated in reviews of the subject (Harrison and Wallace 1990, Richmond 1997), the most studied species of the genus in terms of reproduction is Pocillopora damicornis (Linnaeus 1758). This coral is distributed from the Red Sea and eastern Africa to the west coast of the American continent, where populations are found from Mexico (Gulf of California) to Ecuador, including all the nearby oceanic islands (Glynn and Ault 2000, Pérez-Vivar et al. 2006). It is also considered the dominant coral in the eastern Pacific (Glynn 2004).

Along the western and central Pacific, P. damicornis incubates the planulae (Ward 1992), and reproduces in austral spring and summer (November to March), on the days of new or full moon. In contrast, in the eastern Pacific (from Caño Island, Costa Rica, to the Galapagos Islands, Ecuador), it shows synchronous spawn of gametes and they mature throughout the year and indifferently during new or full moon (Glynn et al. 1991). Information is lacking on the reproductive biology of hard corals in Mexico, though there are some data on the intensity of recruitment of several species (ReyesBonilla and Calderón-Aguilera 1994, Glynn and LeyteMorales 1997, Medina-Rosas et al. 2005, López-Pérez et al. 2007). This study presents the first evidence of successful reproduction of $P$. damicornis in Mexico, based on the finding of mature gametes ready to be released into the water column. This information is highly relevant considering the current status of the coral communities of the Mexican Pacific, which are in the process of recovery after having been severely affected by the 1997-98 El Niño event (Reyes-Bonilla et al. 2002).

\section{Material and methods}

Samples of $P$. damicornis (ramets of individual colonies) were obtained monthly between May 2001 and July 2002, from the area known as Punta Gaviotas (fig. 1), within La Paz Bay. On the new moon day of each month, Scuba divers collected 20 specimens at $2-5 \mathrm{~m}$ depth $(n=300)$. The corals were fixed in $4 \%$ formol prepared in seawater for a period of $24 \mathrm{~h}$, rinsed in running water for $24 \mathrm{~h}$ and then preserved in $70 \%$ ethyl alcohol (Glynn et al. 1991).

For the histological treatment, the coral ramets were decalcified for $4-10 \mathrm{~h}$ in a solution of $10 \% \mathrm{HCl}$ with $0.7 \mathrm{~g}$ EDTA, $0.008 \mathrm{~g}$ sodium potassium tartrate and $0.14 \mathrm{~g}$ sodium tartrate per liter (Szmant-Froelich et al. 1985, Glynn et al. 1991). The tissue was then immediately rinsed under running water for 

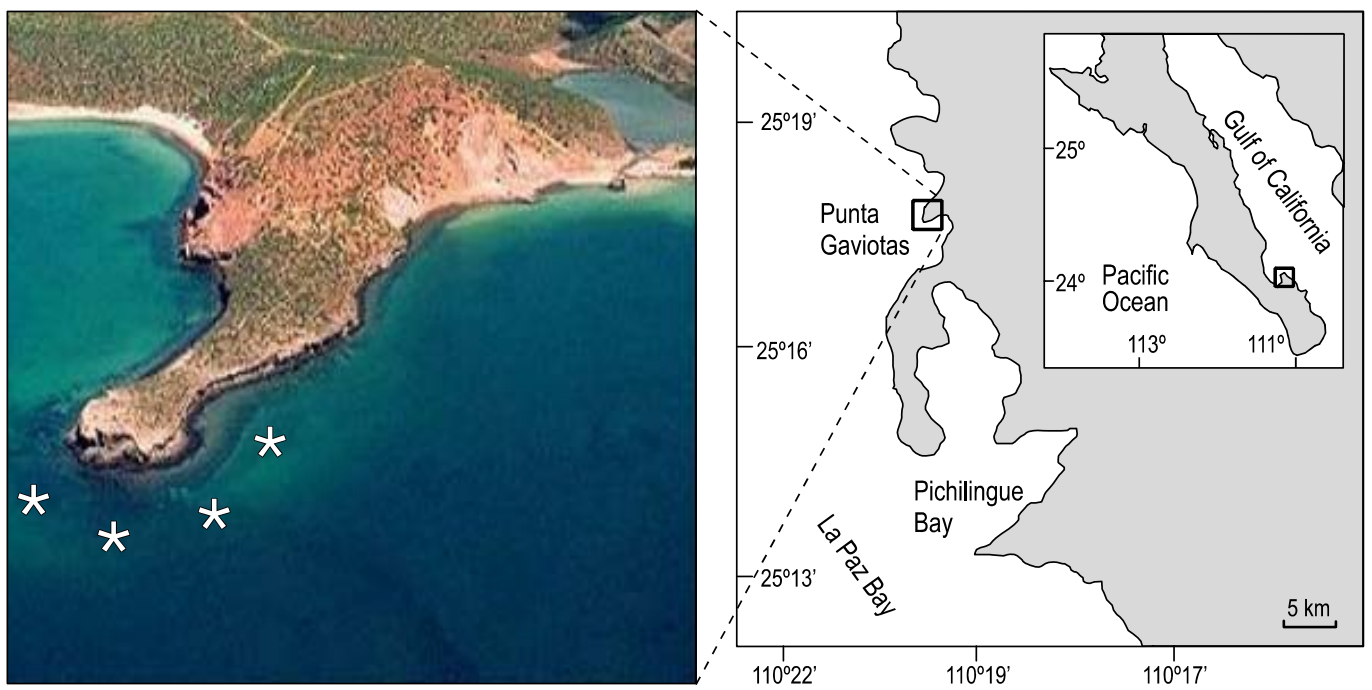

Figura 1. Área de estudio (* sitios de recolecta marcados en la fotografía).

Figure 1. Study area ( ${ }^{*}$ collection sites indicated on the photograph).

Para el tratamiento histológico, las ramas de coral fueron descalcificadas durante 4 a 10 h en una solución de ácido clorhídrico (HCl) al 10\% con 0.7 g de EDTA, 0.008 g de tartrato de sodio y potasio, y $0.14 \mathrm{~g}$ de tartrato de sodio por cada litro (Szmant-Froelich et al. 1985, Glynn et al. 1991). Enseguida, el tejido se enjuagó en agua corriente durante $24 \mathrm{~h}$ con la finalidad de que no quedaran rastros del ácido, y luego las muestras se colocaron en alcohol etílico al 70\%, para eventualmente ser procesadas mediante la técnica histológica convencional (Martoja y Martoja 1970, Humason 1979). Los cortes se tiñeron con hematoxilina férrica-eosina, y para identificar las estructuras reproductoras se utilizaron los criterios propuestos por Szmant-Froelich et al. (1985) y Glynn et al. (1991). Se tomaron microfotografías a un aumento de $20 \times$ de cada una de las preparaciones que presentaron gametos, y se obtuvieron mediciones del diámetro mayor de 40 ovocitos usando el programa SigmaScan Pro versión 5.0. Los datos se expresan con base en la ocurrencia o ausencia de gametos en las colonias muestreadas, y la abundancia de colonias con presencia de gametos (estadios I-IV de ovocitos y espermas) se graficó para cada mes en forma de porcentaje del número total de colonias examinadas.

\section{Resultados}

La población de P. damicornis en Punta Gaviotas presentó organismos exclusivamente hermafroditas. Se observaron gametos masculinos y femeninos durante un periodo de seis meses (junio a noviembre) en 2001, y en los últimos tres meses del estudio en 2002 (mayo a julio).

Se presentaron cuatro estadios de desarrollo para ambos tipos de células sexuales. Con respecto a los gametos femeninos, los dos primeros estadios (ovogonias y ovocitos) se caracterizaron por tener células muy pequeñas y redondeadas (las primeras con un diámetro medio de $18 \mu \mathrm{m}$ y un rango de 10 a $21 \mu \mathrm{m}$, y los segundos con un diámetro medio de $35 \mu \mathrm{m}$ y
$24 \mathrm{~h}$ until free of acid and subsequently placed in 70\% ethyl alcohol until processed by conventional histological techniques (Martoja and Martoja 1970, Humason 1979). The sections were stained with ferric hematoxylin and eosin and the reproductive structures were identified following the criteria proposed by Szmant-Froelich et al. (1985) and Glynn et al. (1991). Microphotographs were taken at 20× magnification of each one of the preparations that showed gametes, and largestdiameter measurements were obtained of 40 oocytes using SigmaScan Pro version 5.0 software. Data are expressed based on the occurrence or absence of gametes in the colonies surveyed, and for each month the abundance of colonies containing gametes (oocyte and sperm stages I-IV) was plotted in terms of the percentage of the total number of colonies sampled.

\section{Results}

The organisms of the P. damicornis population at Punta Gaviotas were exclusively hermaphroditic. Male and female gametes were observed during a six-month period (June to November) in 2001 and during the last three months of the study (May to July) in 2002.

Four developmental stages were observed for both types of sexual cells. The first two stages of the female gametes (oogonia and oocytes) are characterized by the presence of very small, round cells (mean diameter of $18 \mu \mathrm{m}$, ranging from 10 to $21 \mu \mathrm{m}$, and of $35 \mu \mathrm{m}$, ranging from 22 to $40 \mu \mathrm{m}$, per stage, respectively) located in the mesoglea of the mesentery. In stage III, oocytes attain a mean diameter of $55 \mu \mathrm{m}$ (ranging from 41 to $79 \mu \mathrm{m}$ ) and commence vitellogenesis. In stage IV, oocytes reach maturity (mean diameter of $145 \mu \mathrm{m}$, ranging from 80 to $193 \mu \mathrm{m}$ ) and show large amounts of lipid vacuoles as well as vitellus within the cytoplasm; migration of zooxanthellae into the oocyte's cytoplasm was also observed (fig. 2). 
un rango de 22 a $40 \mu \mathrm{m}$ ) que se localizan en la mesoglea del mesenterio. En el estadio III los ovocitos alcanzan un diámetro medio de $55 \mu \mathrm{m}$ (rango de 41 a $79 \mu \mathrm{m}$ ), y comienzan la vitelogénesis. En el estadio IV los ovocitos alcanzaron la madurez (diámetro medio de $145 \mu \mathrm{m}$, rango de 80 a $193 \mu \mathrm{m}$ ) y se distinguieron por presentar una gran cantidad de vacuolas lipídicas, así como vitelo en el citoplasma; además se observó migración de las zooxantelas hacia dentro del citoplasma del ovocito (fig. 2).

En los espermarios, el estadio I se caracteriza por la presencia de células intersticiales muy pequeñas localizadas cerca o dentro de la mesoglea; en el estadio II éstos presentan en su interior espermatocitos agrupados en racimos, mientras que en el estadio III tienen espermátides en gran cantidad, aunque aún no aparecen los flagelos. En el estadio IV aparecen los espermatozoides (gametos ya maduros, flagelados), los cuales presentan un arreglo en forma de ramillete en dirección al centro del espermario (fig. 3).

Con respecto a la aparición de gametos maduros, los ovocitos IV se evidenciaron de agosto a noviembre en 2001, y el porcentaje más alto de colonias con ovocitos maduros (75\% del total muestreado) se presentó en el mes de septiembre (fig. 4). En 2002 sólo se observaron ovocitos maduros durante el mes de julio, y en $10 \%$ de las colonias (fig. 4). Los espermatozoides fueron evidentes a partir de agosto y su aparición continuó hasta noviembre (fig. 5). El mayor porcentaje de colonias con espermatozoides fue de $70 \%$ durante el mes de septiembre. En 2002 los espermatozoides sólo aparecieron en junio, en $5 \%$ de las colonias (fig. 5).

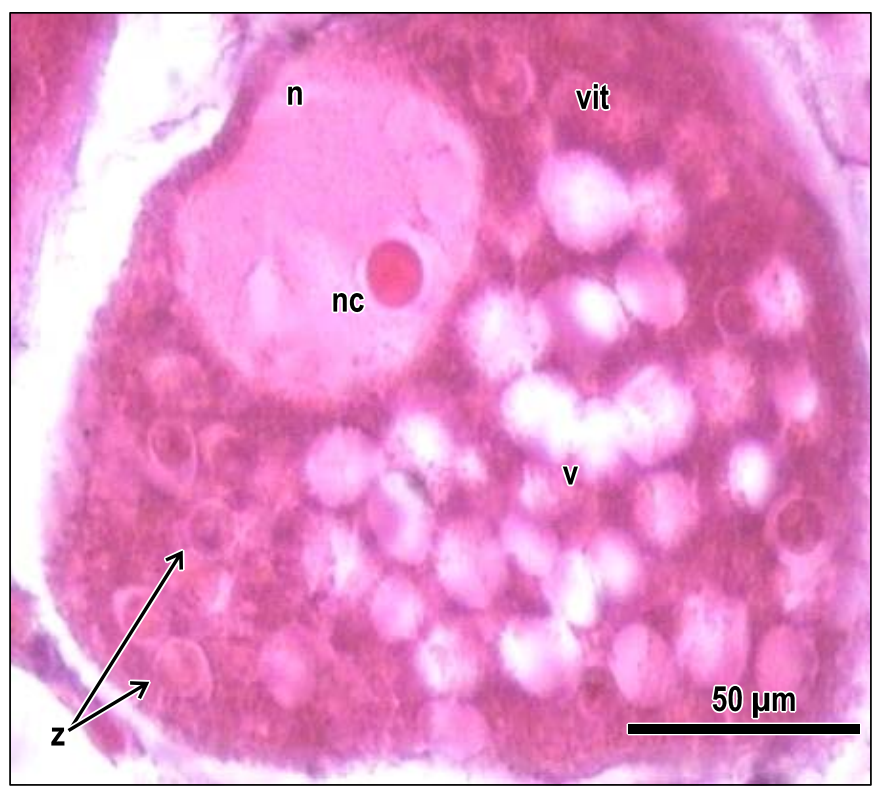

Figura 2. Estadio IV. Ovocito en etapa madura de Pocillopora damicornis; las zooxantelas están presentes en el citoplasma: $\mathrm{n}=$ núcleo, $\mathrm{nc}=$ nucleolo, vit $=$ vitelo, $v=$ vacuolas lipídicas, $z=$ zooxantelas. $40 x$.

Figure 2. Stage IV. Mature oocyte of Pocillopora damicornis; zooxanthellae present in the cytoplasm: $\mathrm{n}=$ nucleus, $\mathrm{nc}=$ nucleolus, vit $=$ vitellus, $\mathrm{v}=$ lipid vacuoles, $z=$ zooxanthellae. $40 x$.
Within the spermarie, stage I is characterized by the presence of very small interstitial cells located near or within the mesoglea, while in stage II spermatocytes are grouped in clusters. In stage III the spermarie shows large amounts of spermatids, though the flagella have still not appeared. In stage IV, spermatozoids (mature, flagellated gametes) appear as a bouquet-like structure towards the middle of the spermarie (fig. 3).

Regarding the appearance of mature gametes, stage IV oocytes were observed from August to November 2001, and the highest percentage of colonies containing mature oocytes (75\% of the total) occurred in September (fig. 4). In 2002, mature oocytes were only observed in July and in $10 \%$ of the colonies (fig. 4). Spermatozoids were evident from August to November 2001 (fig. 5), and September had the highest percentage of colonies containing spermatozoids (70\%). In 2002, spermatozoids only appeared in June and in $5 \%$ of the colonies (fig. 5).

\section{Discussion}

In the study area, P. damicornis was found to be a hermaphroditic coral. Its reproductive activity peaked in summer and autumn (figs. 4, 5), when the species did not produce planulae but rather mature gametes; this coincides with that reported by Glynn et al. (1991). Such gametes are ready to be released into the environment where fertilization and development of the planulae will occur, though these events were not observed in the field. The strategy of gamete broadcasting

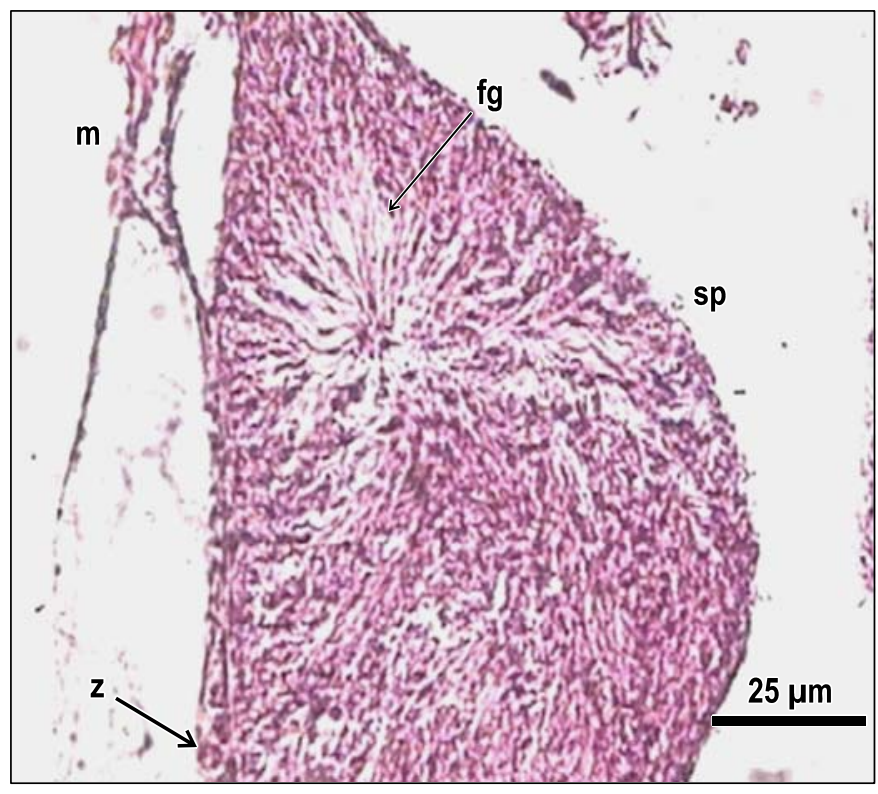

Figura 3. Estadio IV. Espermatozoides de Pocillopora damicornis; se observa la presencia de flagelos en las células: $\mathrm{m}=$ mesenterio, $\mathrm{sp}=$ espermario, $\mathrm{fg}=$ flagelos, $\mathrm{z}=$ zooxantelas. $20 \mathrm{x}$.

Figure 3. Stage IV. Spermatozoa of Pocillopora damicornis; flagella present in the cells: $m=$ mesentery, $s p=$ spermarie, $f g=$ flagella, $z=$ zooxanthellae. 20x. 


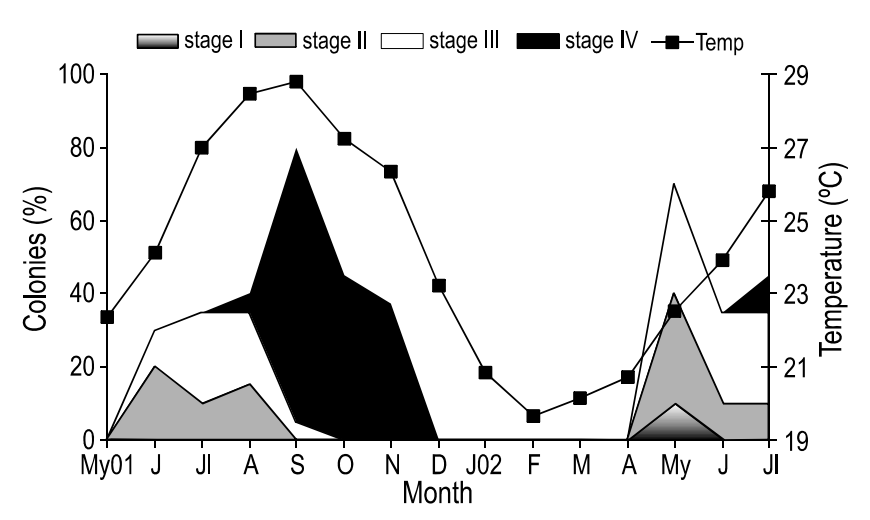

Figura 4. Proporción mensual de estadios gonádicos (ovogénesis) en Pocillopora damicornis durante 2001 y 2002 y su relación con la temperatura superficial del agua; $n=20$ colonias por mes. My01 = mayo de 2001 y $\mathrm{J02}=$ enero de 2002 (www.cdc.noaa.gov/cdc/ data.reynolds_sst.html).

Figure 4. Monthly proportion of gonadal stages (oogenesis) in Pocillopora damicornis during 2001 and 2002, and their relation to surface water temperature; $n=20$ colonies per month. My01 = May 2001 and $\mathrm{J02}=$ January 2002 (www.cdc.noaa.gov/cdc/data.reynolds_sst.html).

\section{Discusión}

En la zona de estudio $P$. damicornis se comportó como un coral hermafrodita, con un pico de actividad reproductiva durante verano y otoño (figs. 4, 5). En esa temporada la especie no produjo plánulas sino gametos maduros, lo cual coincide con las observaciones de Glynn et al. (1991). Tales gametos están listos para ser liberados al medio donde posteriormente se lleve a cabo la fecundación y el desarrollo de las plánulas, aunque estos eventos no se observaron en el campo. La estrategia de emisión de gametos (broadcasting; Harrison y Wallace 1990) tiene sentido si la posibilidad de encuentro de células sexuales es alta, y aparentemente ello está relacionado con el hallazgo de que la maduración de los gametos masculinos y femeninos en Punta Gaviotas fue sincrónica (figs. 4, 5). En general tal coordinación requiere de factores externos al individuo para suceder, y nosotros proponemos que la pista ambiental es dada por la temperatura del agua, la cual debe ser relativamente alta en verano y otoño en la región de La Paz (figs. 4, 5). Todo esto demuestra que el ciclo reproductivo de $P$. damicornis está claramente influenciado por la temperatura del océano, tanto en México como en América Central (Glynn et al. 1991).

Los ovocitos completamente desarrollados presentaban un gran tamaño (145 $\mu \mathrm{m}$ en promedio, con un rango de 80 a $193 \mu \mathrm{m})$ ya que, como ocurre en general en los corales de fecundación externa, la larva debe contar con la concentración adecuada de lípidos para su desarrollo (Harrison y Wallace 1990). La talla media de los ovocitos maduros encontrada en Punta Gaviotas es notablemente superior a la observada en América Central y las Galápagos (Glynn et al. 1991), lo cual contradice lo observado para otros corales en los que el incremento en latitud causa una disminución en el tamaño de los

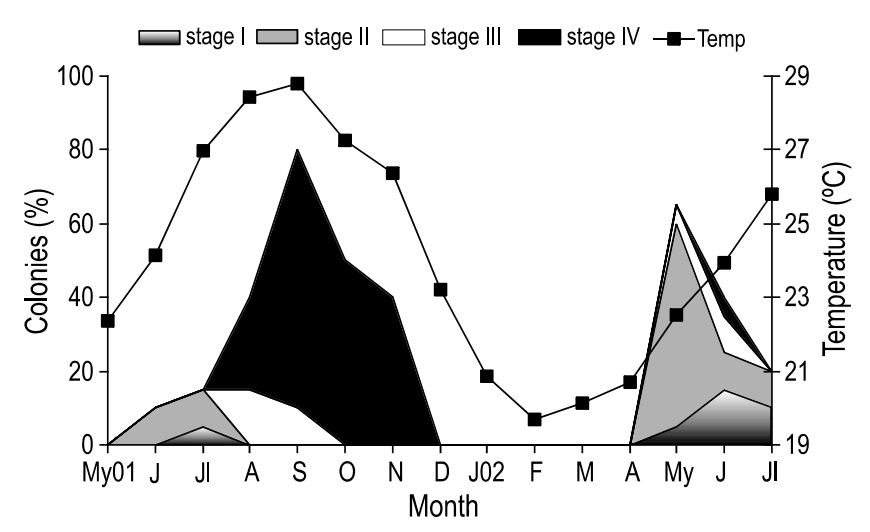

Figura 5. Proporción mensual de estadios gonádicos (espermatogénesis) en Pocillopora damicornis durante 2001 y 2002 y su relación con la temperatura superficial del agua; $n=20$ colonias por mes. My01 = mayo de 2001 y $\mathrm{J02}=$ enero de 2002 (www.cdc.noaa.gov/cdcl data.reynolds_sst.html).

Figure 5. Monthly proportion of gonadal stages (spermatogenesis) in Pocillopora damicornis during 2001 and 2002, and their relation to surface water temperature; $n=20$ colonies per month. My01 = May 2001 and $\mathrm{J02}=$ January 2002 (www.cdc.noaa.gov/cdc/data.reynolds_sst.html).

(Harrison and Wallace 1990) is feasible if the probability of sexual cells meeting is high, and apparently this is related to the synchronous maturation of male and female gametes that occurred at Punta Gaviotas (figs. 4, 5). In general, factors external to the individual are required for such coordination to occur and we propose that water temperature, which tends to be relatively high in summer and autumn in the region of La Paz, is the environmental component (figs. 4, 5). All this shows that the reproductive cycle of $P$. damicornis is clearly influenced by ocean temperature in both Mexico and Central America (Glynn et al. 1991).

The completely developed oocytes attained a large size (145 $\mu \mathrm{m}$ on average, ranging from 80 to $193 \mu \mathrm{m}$ ) because, as usually occurs in externally fertilizing corals, larvae must have the appropriate concentration of lipids for their development (Harrison and Wallace 1990). The mean size of the mature oocytes found at Punta Gaviotas is notably higher than that reported for Central America and the Galapagos Islands (Glynn et al. 1991); this differs from that observed for other corals that show a decrease in female gamete size with an increase in latitude (Harrison 1985). In this regard we can make two observations. First, since the Gulf of California and Central America differ considerably in their oceanographic conditions, our finding emphasizes the influence of the environment as a factor that determines the size and volume of the sexual cells of $P$. damicornis in the eastern Pacific, as has been found for other Indo-Pacific coral species (Wallace 1985, Harrison 1985). Second, the increase in gamete size can indicate a higher concentration of nutritive material in the cells of $P$. damicornis in the gulf and perhaps a greater dispersal ability of these populations. The presence of zooxanthellae in the ovule cytoplasm of P. damicornis (fig. 2) confirms that reported by Glynn et al. (1991) in this respect, and indicates 
gametos femeninos (Harrison 1985). A este respecto podemos hacer dos observaciones: primero, dado que el Golfo de California y las costas de América Central difieren notablemente en sus condiciones oceanográficas, nuestro hallazgo remarca la influencia del ambiente como factor que determina la talla y el volumen de las células sexuales de $P$. damicornis en el Pacífico oriental, tal y como ha ocurrido en otras especies de coral en el Indo Pacífico (Wallace 1985, Harrison 1985). Por otra parte, el aumento en tamaño de los gametos puede indicar mayor concentración de material nutritivo de las células de $P$. damicornis en el golfo, y quizá una mayor capacidad de dispersión de estas poblaciones. Por otro lado, la presencia de zooxantelas dentro del citoplasma del óvulo de $P$. damicornis (fig. 2) confirma las observaciones de Glynn et al. (1991) al respecto, e indica que la plánula cuenta con fuentes alternativas de energía (los carbohidratos y lípidos translocados desde el simbionte). Todo ello apoya la hipótesis que sugiere que $P$. damicornis produce larvas teleplánicas, capaces de permanecer libres por largo tiempo en la columna de agua (Richmond 1987). Finalmente, la herencia materna de zooxantelas es en sí misma un fenómeno interesante ya que normalmente sólo ocurre en especies anidantes y/o hermafroditas (Harrison y Wallace 1990), por lo que debe recibir mayor atención en estudios futuros.

El hallazgo de gametos maduros en el sur del Golfo de California sugiere que en esta región $P$. damicornis se reproduce exitosamente por lo menos una vez al año, lo que aporta nuevas evidencias que fortalecen y corroboran lo observado por Glynn et al. (1991) en Costa Rica, Panamá y las Islas Galápagos, donde la especie también es capaz de reproducirse activamente. Los resultados de todos estos estudios han rebatido el concepto de Richmond (1987) en el sentido de que las poblaciones de esta especie en el Pacífico oriental son estériles ("pseudopoblaciones"), basado en la ausencia de gametos maduros y plánulas en un estudio realizado en Panamá.

A pesar de que se encontró evidencia inequívoca de madurez reproductiva de $P$. damicornis en Punta Gaviotas durante un periodo de cinco meses, con el diseño de muestreo utilizado no fue posible saber si las colonias individuales de la especie desarrollan gametos una o más veces al año. Esto podría considerarse ya que se encontraron colonias con gametos femeninos y masculinos en etapas tempranas de desarrollo (estadios II o III) en meses de alta actividad reproductiva de la especie (figs. 4, 5). Tal situación puede representar una estrategia de reproducción diseñada para maximizar el éxito reproductivo individual. Finalmente, es importante remarcar que además de emplear la reproducción sexual, las poblaciones de $P$. damicornis en el sur del Golfo de California aprovechan eficientemente la fragmentación, pues se ha observado que los parches de esta especie colonizan con facilidad sustratos blandos (arena, gravas) a partir del desprendimiento de ramas luego de los ciclones, las cuales se anclan al fondo y continúan su desarrollo (Reyes-Bonilla 2003).

Los hallazgos descritos en este trabajo tienen gran importancia para propósitos de manejo. La reproducción activa de $P$. that the planulae have alternate sources of energy (carbohydrates and lipids translocated from the symbiont). This supports the hypothesis that $P$. damicornis produces teleplanic larvae that are capable of remaining in the water column for a long time (Richmond 1987). Finally, maternal inheritence of zooxanthellae is in itself an interesting phenomenon since it normally only occurs in brooders and/or hermaphrodite species (Harrison and Wallace 1990), and it should therefore receive greater attention in future studies.

The finding of mature gametes in the Gulf of California indicates that reproduction of $P$. damicornis occurs successfully at least once a year in this region, providing new evidence that supports that found by Glynn et al. (1991) in Costa Rica, Panama and the Galapagos Islands, where the species is also reproductively active. The results of these studies have refuted the concept proposed by Richmond (1987), who based on the absence of mature gametes and planulae larvae in a study conducted in Panama, stated that the populations of this species in the eastern Pacific are sterile ("pseudopopulations").

Even though we found unequivocal evidence of the reproductive maturity of $P$. damicornis at Punta Gaviotas over a five-month period, our sampling design did not allow us to determine whether individual colonies of the species develop gametes only once a year or more than once a year. The latter should be considered since colonies containing male and female gametes in early stages of development (stages II or III) were found during months of high reproductive activity (figs. 4, 5). This situation could represent a reproductive strategy designed to maximize individual reproductive success. Finally, it is important to emphasize that in addition to sexual reproduction, fragmentation also occurs efficiently in $P$. damicornis populations in the southern Gulf of California. Patches of this species have been observed to easily colonize soft substrates (sand, gravel) after their branches become detached following cyclones; these branches attach themselves to the bottom and continue developing (Reyes-Bonilla 2003).

The findings described in this study are highly relevant for management purposes. The active reproduction shown by $P$. damicornis opens the possibility of larval reseeding in La Paz Bay, which should increase the populations' genetic variability and resistance to disturbances. On the other hand, the release of gametes into the water column and maternal inheritance of zooxanthellae indicates that planulae can remain free long enough to maintain considerable levels of connectivity among populations of the species in the Gulf of California and perhaps the rest of the Mexican Pacific, as has been suggested in recruitment studies (Medina-Rosas et al. 2005, López-Pérez et al. 2007); however, this hypothesis has to be proven using molecular tools.

\section{Acknowledgements}

We acknowledge the logistical support received through SEMARNAT-CONACYT project 37528B, directed by LE Calderón-Aguilera (CICESE). The first author was the 
damicornis abre la posibilidad de que exista resiembra larval dentro de la Bahía de La Paz, lo cual debe incrementar la variabilidad genética y la resistencia de las poblaciones a las perturbaciones. Por otra parte, la liberación de gametos a la columna de agua y la herencia materna de las zooxantelas sugiere que las plánulas pueden permanecer libres el tiempo suficiente para mantener niveles apreciables de conectividad entre poblaciones de la especie en el Golfo de California y quizá el resto del Pacífico mexicano, como se ha sugerido en estudios de reclutamiento (Medina Rosas et al. 2005, LópezPérez et al. 2007); sin embargo, esta hipótesis debe demostrarse con herramientas moleculares.

\section{Agradecimientos}

Este estudio fue apoyado logísticamente por el proyecto SEMARNAT-CONACYT "Evaluación de los efectos de El Niño 1997-98 en arrecifes coralinos del Pacífico mexicano", clave 37528 B, bajo la dirección de LE Calderón-Aguilera (CICESE, Ensenada). El CONACYT también ha otorgado becas de licenciatura y maestría al primer autor, gracias a las cuales se pudo desarrollar la investigación y el manuscrito. Se agradece el apoyo, los comentarios y las sugerencias para la revisión histológica de los organismos por parte de C RangelDávalos y MC Gómez del Prado Rosas (UABCS). Las muestras fueron obtenidas por el grupo de trabajo conformado por $\mathrm{F}$ López, A Olivera, H Ruiz, S Scarry-González, A González, I Suárez y JC Solís, ex-alumnos de la UABCS.

\section{Referencias}

Glynn PW. 2004. High complexity food webs in low-diversity eastern Pacific reef-coral communities. Ecosystems 7: 358-367.

Glynn PW, Leyte-Morales GE. 1997. Coral reefs of Huatulco, West Mexico: Reef development in upwelling Gulf of Tehuantepec. Rev. Biol. Trop. 45: 1033-1047.

Glynn PW, Ault JS. 2000. A biogeographic analysis and review of the far eastern Pacific coral reef region. Coral Reefs 19: 1-23.

Glynn PW, Gassman NJ, Eakin CM, Cortés J, Smith DB, Guzmán HM. 1991. Reef coral reproduction in the eastern Pacific: Costa Rica, Panama, and Galápagos Islands (Ecuador). I. Pocilloporidae. Mar. Biol. 109: 355-368.

Harrison PC. 1985. Sexual characteristics of Scleractinian corals: Systematic and evolutionary implications. Proc. 5th Coral Reef Cong. Tahiti. 4: 337-342.

Harrison PL, Wallace CC. 1990. Reproduction, dispersal and recruitment of Scleractinian corals. In: Dubinsky Z (ed.), Ecosystems of the World: Coral Reefs. Elsevier, Amsterdam, pp. 133-207.

Highsmith R. 1982. Reproduction by fragmentation in corals. Mar. Ecol. Prog. Ser. 7: 207-226.

Humason GL. 1979. Animal Tissue Techniques. Freeman, San Francisco, 429 pp.

López-Pérez RA, Mora-Pérez MG, Leyte-Morales GE. 2007. Coral (Anthozoa: Scleractinia) recruitment at Bahías de Huatulco, Mexico: implications for coral community structure and dynamics. Pac. Sci. 61: 355-369. recipient of undergraduate and postgraduate scholarships from CONACYT, without which this study would not have been possible. We thank C Rangel-Dávalos and MC Gómez del Prado Rosas (UABCS) for their support and suggestions during the histological analyses of the organisms. The samples were obtained by F López, A Olivera, H Ruiz, S ScarryGonzález, A González, I Suárez and JC Solís, ex-students of UABCS.

English translation by Christine Harris.

Martoja R, Martoja PM. 1970. Técnicas de Histología Animal. TorayMasson, Barcelona, 350 pp.

Medina-Rosas P, Carriquiry JD, Cupul-Magaña AL. 2005. Reclutamiento de Porites (Scleractinia) sobre sustrato artificial en arrecifes afectados por El Niño 1997-98 en Bahía de Banderas, Pacífico mexicano. Cienc. Mar. 31: 103-109.

Pérez-Vivar TL, Reyes-Bonilla H, Padilla C. 2006. Corales pétreos (Scleractinia) de las Islas Marías, Pacífico de México. Cienc. Mar. 32: 259-270.

Reyes-Bonilla H. 2003. Coral reefs of the Pacific coast of Mexico. In: Cortés J (ed.), Latin American Coral Reefs. Elsevier, Amsterdam, pp. 331-349.

Reyes-Bonilla H, Calderón-Aguilera LE. 1994. Parámetros poblacionales de Porites panamensis (Anthozoa: Scleractinia), en el arrecife de Cabo Pulmo, México. Rev. Biol. Trop. 42: 121-128.

Reyes-Bonilla H, Carriquiry JD, Leyte-Morales GE, Cupul-Magaña AL. 2002. Effects of the El Niño-Southern Oscillation and the anti-El Niño event (1997-1999) on coral reefs of the western coast of Mexico. Coral Reefs 21: 368-372.

Richmond RH. 1987. Energetic relationships and biogeographical differences among fecundity, growth, and reproduction in the reef coral, Pocillopora damicornis. Bull. Mar. Sci. 41: 594-604.

Richmond RH. 1997. Reproduction and recruitment in corals: Critical links in the persistence of reefs. In: Birkeland C (ed.), Life and Death of Coral Reefs. Chapman and Hall, New York, pp. 175197.

Richmond RH, Hunter CL. 1990. Reproduction and recruitment of corals: Comparisons among the Caribbean, the tropical Pacific, and the Red Sea. Mar. Ecol. Prog. Ser. 60: 185-203.

Stoddart JA. 1983. Asexual production of planulae in the coral Pocillopora damicornis. Mar. Biol. 76: 279-284.

Stoddart JA, Black R. 1985. Cycles of gametogenesis and planulation in the coral Pocillopora damicornis. Mar. Ecol. Prog. Ser. 23: 153-164.

Szmant-Froelich A, Reutter M, Riggs L. 1985. Sexual reproduction of Favia fragum (Esper): Lunar patterns of gametogenesis, embryogenesis and planulation in Puerto Rico. Bull. Mar. Sci. 37: 880-892.

Wallace CC. 1985. Reproduction, recruitment and fragmentation in nine sympatric species of the coral genus Acropora. Mar. Biol. 88: 217-223.

Ward S. 1992. Evidence for broadcast spawning as well as brooding in the Scleractinian coral Pocillopora damicornis. Mar. Biol. 112: 641-646.

Recibido en febrero de 2007; aceptado en agosto de 2007. 